\title{
A new recombinant factor VIII: from genetics to clinical use
}

\author{
This article was published in the following Dove Press journal: \\ Drug Design, Development and Therapy \\ 23 July 2015 \\ Number of times this article has been viewed
}

\author{
Christoph Kannicht ${ }^{1}$ \\ Guido Kohla' \\ Maya Tiemeyer ${ }^{2}$ \\ Olaf Walter ${ }^{3}$ \\ Helena Sandberg ${ }^{4}$ \\ 'Octapharma Biopharmaceuticals \\ $\mathrm{GmbH}$, Molecular Biochemistry, \\ Berlin, Germany; ${ }^{2}$ Octapharma \\ Biopharmaceuticals $\mathrm{GmbH}$, \\ Heidelberg, Germany; ${ }^{3}$ Octapharma \\ AG, Lachen, Switzerland; ${ }^{4}$ CoaBio AB, \\ Bromma, Sweden
}

\section{Dear editor}

The December 2014 issue of Drug Design, Development and Therapy included a review article by Santagostino entitled "A new recombinant factor VIII: from genetics to clinical use". ${ }^{1}$ The article provided a timely review of recent advances and developments in the treatment of hemophilia A with recombinant factor VIII (rFVIII). ${ }^{1}$ However, when reviewing licensed rFVIII products, Santagostino ${ }^{1}$ did not include Human-cl rhFVIII ( simoctocog alfa, Nuwiq $\left.{ }^{\circledR}\right) .^{2-4}$ Nuwiq $^{\circledR}$ is a new-generation rFVIII protein produced in HEK 293 F cells that was approved by the European Medicines Agency in July 2014 for the prevention and treatment of bleeds in hemophilia A patients of all ages. ${ }^{5}$

Santagostino $^{1}$ described the gradual improvements made to rFVIII production/ formulation and how these have coincided with the introduction of first-, second-, and third-generation rFVIII products, particularly in relation to the elimination of productionrelated additives from animal/human sources and viral removal/inactivation. These developments were summarized in Table 1 of the article, ${ }^{1}$ which is adapted here with an additional row providing the respective information for Nuwiq ${ }^{\circledR}$ (Table 1).

The Nuwiq ${ }^{\circledR}$ production process is entirely free of additives of animal or human origin. ${ }^{2}$ In addition, the purification process for Nuwiq ${ }^{\circledR}$ has incorporated technological advances into a multi-step process involving one centrifugation, two filtration, and five chromatography steps, including two dedicated virus clearance steps (solvent/ detergent treatment and $20 \mathrm{~nm}$ nanofiltration). ${ }^{2}$

Santagostino $^{1}$ further described the protein structure of FVIII and the importance of post-translational modifications, importantly pointing out that "sulfation is required for full activity of FVIII" and that "glycosylation influences stability and modulates immunogenic properties". With respect to sulfation, Santagostino focused on sulfation of tyrosine 1680, which is a prerequisite for complex formation with VWF and influences the half-life of FVIII in the circulation. ${ }^{1}$ Table 3 of the article ${ }^{1}$ cited mass spectrometry data reported by Kannicht et $\mathrm{al}^{4}$ relating to non-sulfated Tyr1680 in hamster-derived rFVIII products, but did not report data for Nuwiq ${ }^{\circledR}$ from the same article, ${ }^{4}$ which indicated that the amount of non-sulfated Tyr1680 present in Nuwiq ${ }^{\circledR}$ was below the level of detection. In addition, Sandberg et $\mathrm{al}^{3}$ reported a higher VWFbinding affinity for Nuwiq ${ }^{\circledR}$ compared with Advate $^{\circledR}$, Kogenate ${ }^{\circledR}$ or ReFacto ${ }^{\circledR}$. Table 3 of the review by Santagostino ${ }^{1}$ is adapted here with an additional row providing the respective information for Nuwiq ${ }^{\circledR}$ (Table 2).

With respect to glycosylation, Santagostino ${ }^{1}$ focused on the glycosylation patterns of turoctocog alfa $\left(\right.$ NovoEight $\left.^{\circledR}\right)$ and concluded that:
Correspondence: Christoph Kannicht Octapharma Biopharmaceuticals GmbH, Molecular Biochemistry, Walther-NernstStr 3, D-12489, Berlin, Germany

Tel +493083227360

Fax +493084109862

Email christoph.kannicht@octapharma.com 
Table I Licensed recombinant factor VIII products

\begin{tabular}{|c|c|c|c|c|c|c|}
\hline Generation & $\begin{array}{l}\text { Product } \\
\text { (manufacturer) }\end{array}$ & FVIII & Cell line & Culture medium & Stabilizer & $\begin{array}{l}\text { Purification/viral } \\
\text { inactivation }\end{array}$ \\
\hline First & $\begin{array}{l}\text { Recombinate }^{\circledR} \\
\text { (Baxter BioScience) }\end{array}$ & Full-length & $\mathrm{CHO}$ & $\begin{array}{l}\text { Bovine serum } \\
\text { albumin }\end{array}$ & $\begin{array}{l}\text { Human } \\
\text { albumin }\end{array}$ & IAC/IEC \\
\hline Second & $\begin{array}{l}\text { Kogenate }^{\circledast} \text { FS } \\
\text { (Bayer Healthcare) }\end{array}$ & Full-length & BHK & $\begin{array}{l}\text { Human plasma } \\
\text { protein solution }\end{array}$ & Sucrose & IAC/IEC/SD/UF \\
\hline Second & $\begin{array}{l}\text { Helixate }^{\circledR} \text { FS } \\
\text { (CSL Behring) }\end{array}$ & Full-length & BHK & $\begin{array}{l}\text { Human plasma } \\
\text { protein solution }\end{array}$ & Sucrose & IAC/IEC/SD/UF \\
\hline Third & $\begin{array}{l}\text { Advate }^{\circledR} \\
\text { (Baxter Healthcare) }\end{array}$ & Full-length & $\mathrm{CHO}$ & None & Trehalose & $\mathrm{IAC/IEC/SD}$ \\
\hline Third & $\begin{array}{l}\text { Xyntha/ReFacto }{ }^{\circledR} \mathrm{AF} \\
\text { (Pfizer) }\end{array}$ & B-domain-deleted & $\mathrm{CHO}$ & None & Sucrose & $\mathrm{IAC/IEC/SD/NF}$ \\
\hline Third & $\begin{array}{l}\text { Turoctocog alfa } \\
\text { (Novo Nordisk) }\end{array}$ & $\begin{array}{l}\text { B-domain- } \\
\text { truncated }\end{array}$ & $\mathrm{CHO}$ & None & Sucrose & IAC/IEC/SD/NF/SE \\
\hline New & $\begin{array}{l}\text { Nuwiq } \\
\text { (Octapharma AG) }\end{array}$ & B-domain-deleted & HEK & None & $\begin{array}{l}\text { Sucrose/ } \\
\text { arginine }\end{array}$ & IAC/IEC/SD/NF/SE \\
\hline
\end{tabular}

Note: Copyright @ 2014. Dove Medical Press. Adapted from Santagostino E. A new recombinant factor VIII: from genetics to clinical use. Drug Des Devel Ther. 20I4;8: 2507-25 I5.' Additional data added for Nuwiq ${ }^{\circledR} .^{2-4}$

Abbreviations: FVIII, factor VIII; IAC, immunoaffinity chromatography; IEC, ion exchange chromatography; NF, nanofiltration; SD, solvent/detergent treatment; SE, size exclusion; UF, ultrafiltration.

Table 2 Levels of non-sulfated tyrosine in rFVIII

\begin{tabular}{llll}
\hline Product & Origin & \multicolumn{2}{l}{ Non-sulfated tyrosine I680 (\%) } \\
\cline { 3 - 4 } & & LC-MS/MS & LC-MS/MS \\
\hline Turoctocog alfa & CHO & - & - \\
Full-length, third-generation rFVIII & CHO & $2.6-16.7$ & $5.0-8.0$ \\
Full-length, second-generation rFVIII & BHK & I-6.5 detection limit \\
BDD third-generation rFVIII & CHO & $4.5-13.9$ & 1.5 \\
Simoctocog alfa, BDD & HEK & - & $4.0-5.0$ \\
new-generation rFVIII & & & Below detection limit
\end{tabular}

Notes: Levels of non-sulfated tyrosine in rFVIII included Advate ${ }^{\circledR}$ (full-length third-generation rFVIII), Kogenate $\mathrm{FS}^{\circledR}$ (full-length second-generation rFVIII), and Xyntha/ReFacto $\mathrm{AF}^{\circledR}$ (B-domain-deleted third-generation rFVIII). The sulfated form dominated for all proteins, with the proportion of non-sulfated tyrosine 1680 being highest for some thirdgeneration rFVIII products. A small peak for the non-sulfated isoform was also observed for second-generation rFVIII, while no non-sulfated species were detected for turoctocog alfa or Nuwiq ${ }^{\circledR}$ (B-domain-deleted new-generation rFVIII). Below detection limit means negligible signal, $<1 \%$, or $<0.5 \%$, trace. Copyright $\left({ }^{\circ} 2014\right.$. Dove Medical Press. Adapted from Santagostino E. A new recombinant factor VIII: from genetics to clinical use. Drug Des Devel Ther. 20I4;8:2507-25I5.'

Abbreviations: BDD, B-domain-deleted; LC-MS/MS, liquid chromatography tandem mass spectrometry; rFVIII, recombinant factor VIII; MS-FT, mass spectrometry high resolution Fourier transform scan.

The oligosaccharide structures of the novel rFVIII [Novo-

Eight $\left.{ }^{\circledR}\right]$ and plasma-derived FVIII are very similar, with mainly small, quantitative differences, and heterogeneous glycosylation is present in both products.

Comparable glycosylation of Nuwiq ${ }^{\circledR}$ and plasma-derived FVIII has also been reported. ${ }^{4}$ It is well documented that potentially antigenic non-human glycan epitopes, such as $N$-glycolylneuraminic acid (Neu5Gc) or Gal- $\alpha 1-3 \mathrm{Gal} \beta 1$ (3) 4 GlcNAc-R ( $\alpha-\mathrm{Gal})$, are present in recombinant products derived from hamster cells., ${ }^{4,6,7}$ Thus, a comparison of these epitopes in rFVIII products derived from hamster cells might have been of interest to your readers. As Nuwiq ${ }^{\circledR}$ is produced in a human cell line, Neu5Gc or $\alpha$-Gal are not present. ${ }^{4}$

In summary, the Santagostino article $^{1}$ was a welcome addition to the literature that provided a timely update on recent advances and developments in rFVIII treatment of hemophilia A. However, the omission of data for the newgeneration human cell derived rFVIII, Nuwiq ${ }^{\circledR}$, which have been summarized in this letter, was a major limitation of the article. ${ }^{1}$

\section{Disclosure}

Christoph Kannicht, Guido Kohla, Maya Tiemeyer, Olaf Walter are employees of Octapharma. Helena Sandberg is a former employee of Octapharma. Editorial assistance was provided by nspm 1td, Meggen, Switzerland, with financial support from Octapharma.

\section{References}

1. Santagostino E. A new recombinant factor VIII: from genetics to clinical use. Drug Des Devel Ther. 2014;8:2507-2515.

2. Casademunt E, Martinelle K, Jernberg M, et al. The first recombinant human coagulation factor VIII of human origin: human cell line and manufacturing characteristics. Eur J Haematol. 2012;89(2):165-176. 
3. Sandberg H, Kannicht C, Stenlund P, et al. Functional characteristics of the novel, human-derived recombinant FVIII protein product, human-cl rhFVIII. Thromb Res. 2012;130(5):808-817.

4. Kannicht C, Ramstrom M, Kohla G, et al. Characterisation of the posttranslational modifications of a novel, human cell line-derived recombinant human factor VIII. Thromb Res. 2013;131(1):78-88.

5. European Medicines Agency [homepage on the Internet]. Nuwiq simoctocog alfa (rFVIII); 2014 [updated December 19, 2014]. Available from: http://www.ema.europa.eu/ema/index.jsp?curl=pages/ medicines/human/medicines/002813/human_med_001781. jsp\&mid=WC0b01ac058001d124. Accessed April 16, 2015.
6. Hokke CH, Bergwerff AA, van Dedem GW, et al. Sialylated carbohydrate chains of recombinant human glycoproteins expressed in Chinese hamster ovary cells contain traces of $\mathrm{N}$-glycolylneuraminic acid. FEBS Lett. 1990;275(1-2):9-14.

7. Hironaka T, Furukawa K, Esmon PC, et al. Comparative study of the sugar chains of factor VIII purified from human plasma and from the culture media of recombinant baby hamster kidney cells. J Biol Chem. 1992;267(12):8012-8020.

Dove Medical Press encourages responsible, free and frank academic debate. The content of the Drug Design, Development and Therapy 'letters to the editor' section does not necessarily represent the views of Dove Medical Press, its officers, agents, employees, related entities or the Drug Design, Development and Therapy editors. While all reasonable steps have been taken to confirm the content of each letter, Dove Medical Press accepts no liability in respect of the content of any letter, nor is it responsible for the content and accuracy of any letter to the editor.

\section{Publish your work in this journal}

Drug Design, Development and Therapy is an international, peerreviewed open-access journal that spans the spectrum of drug design and development through to clinical applications. Clinical outcomes, patient safety, and programs for the development and effective, safe, and sustained use of medicines are a feature of the journal, which has also been accepted for indexing on PubMed Central. The manuscript management system is completely online and includes a very quick and fair peer-review system, which is all easy to use. Visit http://www.dovepress.com/testimonials.php to read real quotes from published authors.

Submit your manuscript here: http://www.dovepress.com/drug-design-development-and-therapy-journal 